\title{
INTEGRATION OF GEOPHYSICAL METHODS IN THE STUDY OF ACID DRAINAGE IN URANIUM MINING WASTE
}

\author{
Matheus Felipe Stanfoca Casagrande ${ }^{1}$, César Augusto Moreira² ${ }^{2}$ Débora Andrade Targa ${ }^{1}$ and \\ Heber Luiz Caponi Alberti3
}

\begin{abstract}
Among the potential environmental impacts in mining activities, acid mine drainage (AMD) is a relevant problem caused by reactive minerals, such as sulfides, due to their exposure to the surface conditions. This is the context of contamination of a waste pile (BF-04) at Osamu Utsumi mine, closed in 1995 after years of physical and chemical processing of the uranium ore and currently under decommissioning plan. This study is based on the application of the combined geophysical methods of Electrical Resistivity and Induced Polarization and the analysis of previous geochemical data, aiming the evaluation of zones related to the generation of AMD and groundwater flux into the waste pile BF-04, containing sulfide minerals and uranium. The association of high resistivity and high chargeability zones is related to disseminated sulfide minerals in rock with silica cement. Infiltration of meteoric water through those zones induces the oxidation of sulfides, high sulfur concentration in groundwater followed by a drop in pH values, which results in a higher leaching capacity and solubility of ions and heavy metals. In addition, high chargeability zones (higher than $10 \mathrm{mV} / \mathrm{N}$ ) represent portions of generation of AMD, while the low resistivity anomalies (under $70 \Omega \mathrm{m}$ ) are related to preferential flow zones of the contaminated groundwater.
\end{abstract}

Keywords: minning, sulfides, uranium, electrical resistivity, chargeability.

RESUMO. Dentre os potenciais impactos ambientais em mineração, a drenagem ácida de mina (DAM) é um problema grande onde ocorrem minerais instáveis como os sulfetos, outrora isolados em subsuperfície. É neste contexto de contaminação do meio físico que está inserido uma pilha de rejeitos (BF-04) pertencente à mina de urânio Osamu Utsumi, cujas atividades de mineração, processamento físico e processamento químico foram encerradas em 1995, seguidas pela etapa de descomissionamento até os dias atuais. Neste estudo foram aplicados os métodos geofísicos da Eletrorressitividade e Polarização Induzida combinados com dados geoquímicos prévios, com o intuito de avaliar zonas de geração e fluxo de drenagem ácida de mina na pilha de rejeitos de mineração BF-04 com sulfetos e urânio. A combinação de zonas de alta resistividade e alta cargabilidade revela sulfetos disseminados em rochas com cimento silicático. A infiltração de águas meteóricas nestes locais induz a oxidação de sulfetos, liberação de enxofre nas águas subterrâneas seguida pela queda no pH, que resulta num efluente com alta capacidade de lixiviação e solubilidade de sais e metais. Neste sentido, zonas de alta cargabilidade (acima de $10 \mathrm{mV} / \mathrm{N}$ ) representam locais de geração de drenagem ácida de mina, enquanto que zonas de baixa resistividade (abaixo de $70 \Omega$.m) revelam zonas preferenciais de fluxo do efluente.

Palavras-chave: mineração, sulfetos, urânio, resistividade, cargabilidade.

\footnotetext{
${ }^{1}$ Universidade Estadual Paulista - UNESP, Programa de Pós-graduação em Geociências e Meio Ambiente - Instituto de Geociências e Ciências Exatas, Rio Claro Campus, SP, Brazil-E-mails: mfs-casagrande@hotmail.com, debora.targa@gmail.com

${ }^{2}$ Universidade Estadual Paulista - UNESP, Instituto de Geociências e Ciências Exatas, Departamento de Geologia Aplicada, Rio Claro Campus, SP, Brazil - E-mail: moreirac@rc.unesp.br

${ }^{3}$ Comissão Nacional de Energia Nuclear - CNEN, Laboratório de Poços de Caldas. Pocos de Caldas, MG. Brazil -E-mail: heber@cnen.gov.br
} 


\section{INTRODUCTION}

The mining activity is among the potential sources of groundwater contamination, including dumps, poorly planned landfills, effluents and waste from industrial activities, sewage system overflows, accidents and spills related to fuels and misused agricultural inputs. The contamination potential of the environment is directly related to the characteristics, quantity and form of the contaminant release, as well as to the local aquifer vulnerability (Corseuil \& Marins, 1997; CETESB, 2016).

In the mineral extraction industry, it is widely known its potential for environmental impact, especially in respect to the disposal of tailings and waste coming from the mining asset exploration and processing. Open-pit or underground uranium mines are even more problematic from the environmental standpoint due to innumerous possibilities of the environment contamination, like the soil and water pollution by heavy metals and radio-nuclides, fauna and flora exposure to these elements, and atmospheric contamination by radioactive dust and radon gas, derived from the uranium and thorium decay series (Fernandes et al., 1998; Abdelouas, 2006; Carvalho et al., 2007).

It is worth highlighting the importance of the mining project and of the resulting volume of the explored ore to understand the potential impact set. For its appraisal, the following information is crucial: quantity and composition of the released effluent, temporal evolution of the contaminant and its dispersion in environment, factors to calculate the transference of its components for sensitive species, relation of pollutant concentrations, and relation between affected species and environmental cost (Fernandes et al., 1998).

Sulfide minerals, once isolated in subsurface, and the reaction with atmospheric oxygen in the presence of water produce low pH effluents with high concentrations of metals and metalloids, a process known as acid mine drainage (AMD) (Akcil \& Koldas, 2006). The detection and monitoring of water that is rich in salts dissolved in the subsurface successfully employ geophysical electrical and electromagnetic methods, together with the traditional direct approach of investigation, like monitoring wells, ensuring success in different researches (Silva et al., 2009; Veloso et al., 2015; Helene et al., 2016; Moreira et al., 2017).

This article aims a geophysical diagnosis by means of an association of the methods of electroresistivity and induced polarization in a tailings pile (dumps) of uranium and sulfide mining, where there is the generation of acid mine drainage. The main purpose is to identify the areas where the sulfide concentration and oxidation exist, as well as the preferential flow routes in the pile. The understanding of the processes that generate acid mine drainage and the identification of the locations where they happen may subsidize recovery actions for the environmental liability.

\section{PHYSIOGRAPHIC CHARACTERIZATION OF THE AREA}

The study area consists of a tailings pile, locally called dump pile (BF-04), that results from the exploration and processing of the uranium ore in Poços de Caldas Plateau, south of Minas Gerais. The mined area is Osamu Utsumi mine and it belongs to Unidade de Tratamento de Minérios - UTM, operated by Indústrias Nucleares do Brasil - INB (Fig. 1).

The area was in activity between 1982 and 1995 and the enterprise comprised mining, processing and production of uranium concentrate for use in the Brazilian nuclear plants. The generated environmental liability consists of the old open pit, the tailings pond and the dump piles. This study was developed in one of these piles composed by fragments of rocks with low content of uranium and sulfides, produced during the uranium ore extraction and then released in an old fluvial valley. The hydrogeological monitoring of the environmental liability reveals a record of the AMD generation.

The area has a high-altitude tropical climate with two well defined seasons. The first of them, between October and March, is marked by an intense pluviose and a milder temperature, while from April to September there are a dry period and lower temperatures with casual frosts. The average rainfall index is $1,700 \mathrm{~mm} / \mathrm{year}$, with $80 \%$ of this precipitation concentrated from October to March (Holmes et al., 1992; Cipriani, 2002). The vegetation around the Osamu Utsumi mine is composed of rustic grasses, with a predominance of goat's beard, that characterize the altitude fields. Also there are arboreous and arbustive species disseminated in short stains along the slopes (Cipriani, 2002).

The geological context is represented by the Poços de Caldas Alkaline Complex that is considered one of the largest occurrence of this type in the world. Its intrusion is located in the meridional portion of the Atlantic Shield in Precambrian terrains formed basically by biotite gneiss and anatexites from the Guaxupé Median Massif, near to the northeastern border of the Paraná Basin (Fraenkel et al., 1985). The lithotypes mapped in the area of the Osamu Utsumi mine are essentially composed of nepheline syenites, tinguaites/phonolites, foyaites, breccia and ultrabasic rocks. Additionally, superimposed magmatic 


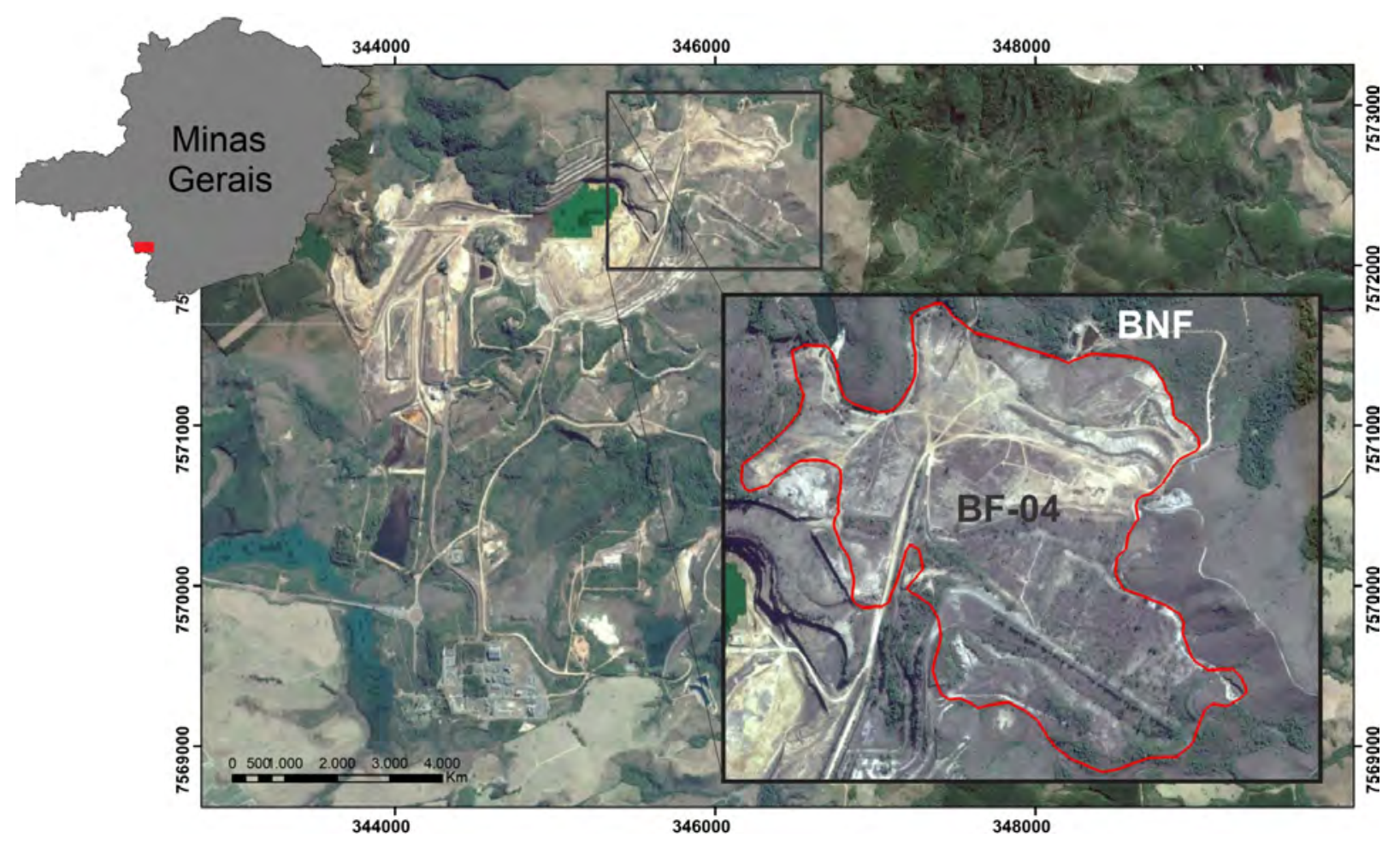

Figure 1 - Location of the study area, with the BF-04 delimitation in the INB facilities.
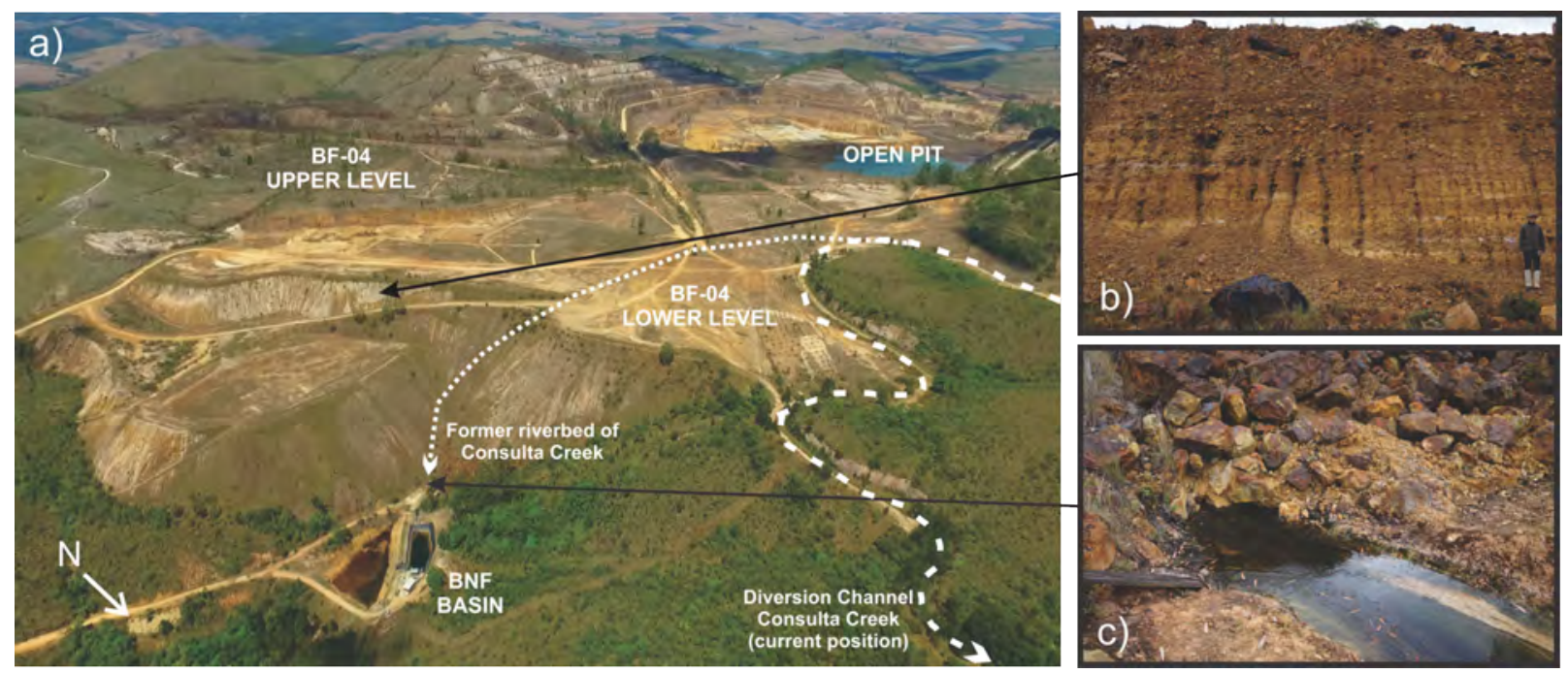

Figure 2 - Aerial image of the BF-04 indicating the levels, pit and artificial channel of the Consulta Creek (a). The details in question depict the waste granulometric variability (b) and the emerged groundwater on the base of the main slope among the metric boulders (c). 
processes of hydrotermal and supergene alteration are identified (Fraenkel et al., 1985; Capovilla, 2001).

\section{Mining enterprise operation}

When the Osamu Utsumi mine was active, its operation was divided into the following steps: mining, physical, and chemical processing. The adopted method was the open pit exploration, which resulted in a pit with a diameter of $1,200 \mathrm{~m}$ and a depth of $200 \mathrm{~m}$ approximately.

The unit was projected to process 2,500 tonnes of uranium ore per day, that would correspond nearly to 700,000 tonnes per year with a soluble uranium content equivalent to $680 \mathrm{ppm}$ of the element. In contrast, it was defined a cut-off grade of 170 ppm of $\mathrm{U}_{3} \mathrm{O}_{8}$ recovered in the plant and the material below this concentration was considered waste and was sent to the unit dump piles, mainly the BF-08 and the BF-04 (Cipriani, 2002).

The BF-04 is located in the northern portion of the Osamu Utsumi mine, near to the old exploration pit. It includes an area of 56.4 ha and its waste volume is 14.26 millions $\mathrm{m}^{3}$, conditioned by $90 \mathrm{~m}$ slopes. Also, it is subdivided into two distinct steps: the upper and the lower levels. The first is constituted mainly by tailings and the second by the sorting of the mineralized body. This second level is more relevant in terms of AMD generation and propagation. The BNF (Nestor Figueiredo Basin) was constructed to hold the acid effluent that pours from the main slope base, where there is the pumping of these waters to the local treatment plant (Fig. 2a).

The construction process was carried out using the end-dumping method. The waste granulometric distribution is very wide and variable in the dump pile, presenting from clay fractions up to boulders. Additionally, there is a waste particle segregation that results from the BF-04 construction process, where the summit is mainly constituted by fine particles and the base by rock blocks with diameters that vary from 0.3 to $1.3 \mathrm{~m}$ (Figs. $2 \mathrm{~b}$ and $2 \mathrm{c}$ ). Also, the construction was made by filling the slope of the Consulta Creek that belongs to Rio Verde Basin. The referred water body was then deviated to the left side of the landfill where a constructed channel drains the system. The water is released downstream the BF-04.

The chemical and mineralogical composition of the waste obviously corresponds to the local alkaline rocks, especially the rocks that present $\mathrm{Si}, \mathrm{Al}$ and $\mathrm{K}$ as the major elements. Potassium feldspar $\left[\mathrm{KAISi}_{3} \mathrm{O}_{8}\right]$, kaolinite $\left[\mathrm{Al}_{2} \mathrm{Si}_{2} \mathrm{O}_{5}(\mathrm{OH})_{4}\right]$, muscovite $\left[\mathrm{KAl}_{2} \mathrm{Si}_{3} \mathrm{AlO}_{10}(\mathrm{OH}, \mathrm{F})_{2}\right]$ and gibbsite $\left[\mathrm{Al}(\mathrm{OH})_{3}\right]$ were identified as the most abundant minerals of the waste, presenting the alteration of feldspars into kaolinite. Differently, the content of pyrite $\left[\mathrm{Fe}_{2} \mathrm{~S}\right]$, considered as the main mineral that causes the AMD process and that exists in the waste, is nearly $2 \%$ (Table 1 ).

Table 1 - Mineralogical composition of the BF-04.

\begin{tabular}{|l|c|c|}
\hline \multirow{2}{*}{ MINERAL } & \multicolumn{2}{|c|}{ Concentration in BF-04 (\%) } \\
\cline { 2 - 3 } & Franklin (2007) & Leite (2010) \\
\hline $\mathrm{BaSO}_{4}$ (Barite) & 2.00 & - \\
\hline $\mathrm{FeO}(\mathrm{OH}$ ) (Goethite) & 2.00 & 6.37 \\
\hline $\mathrm{SiO}_{2}$ (Silica) & 0.04 & - \\
\hline $\left.\mathrm{Al}_{(\mathrm{OH}}\right)_{3}$ (Gibbsite) & 1.25 & 2.50 \\
\hline $\mathrm{Fe}_{2} \mathrm{O}_{3}$ (Hematite) & 1.50 & - \\
\hline $\mathrm{Fe}_{2} \mathrm{O}_{4}$ (Magnetite) & 0.50 & - \\
\hline $\mathrm{FeS}_{2}$ (Pirite) & 2.00 & - \\
\hline $\mathrm{UO}_{2}$ (Uraninite) & 0.12 & - \\
\hline $\mathrm{Al}_{2} \mathrm{Si}_{2} \mathrm{O}_{5}$ (OH) ${ }_{4}$ (Kaolinite) & 20.00 & 34.79 \\
\hline $\mathrm{KAlSi}_{3} \mathrm{O}_{8}$ (Kfeldspar) & 50.00 & 54.85 \\
\hline $\mathrm{CaF}_{2}$ (Fluorite) & 0.42 & - \\
\hline $\mathrm{MnO}_{2}$ (Pyrolusite) & 0.17 & - \\
\hline $\mathrm{KAl}_{3} \mathrm{Si}_{3} \mathrm{O}_{10}$ (OH) $)_{2}$ (Muscovite) & 20.00 & 2.12 \\
\hline
\end{tabular}

In terms of hydrogeology, the characteristics of the BF-04 dump pile are near to the characteristics of a natural porous aquifer over a fractured system, composed by the local alkaline rocks. Nevertheless, the particularities of the construction process and also of the material that constitutes the landfill, especially the granulometric variability, developed a physically heterogeneous environment capable of influencing directly the dynamics of the local underground flow and also the AMD generation.

\section{METHODOLOGY}

In order to characterize and monitor the areas affected by contaminants, it is usual to apply geophysical studies, based on the alteration of the physical proprieties of the natural environment by the presence of electrolytes. A more saline groundwater in a geological environment with a relatively higher resistivity provides an important contrast of the physical parameters of the environment and may be quantified by means of geoelectrical assays, especially the Electroresistivity method (Blowes, 1997; Campbell et al., 2000; Campbell \& Fitterman, 2000; Fachin et al., 2006). 


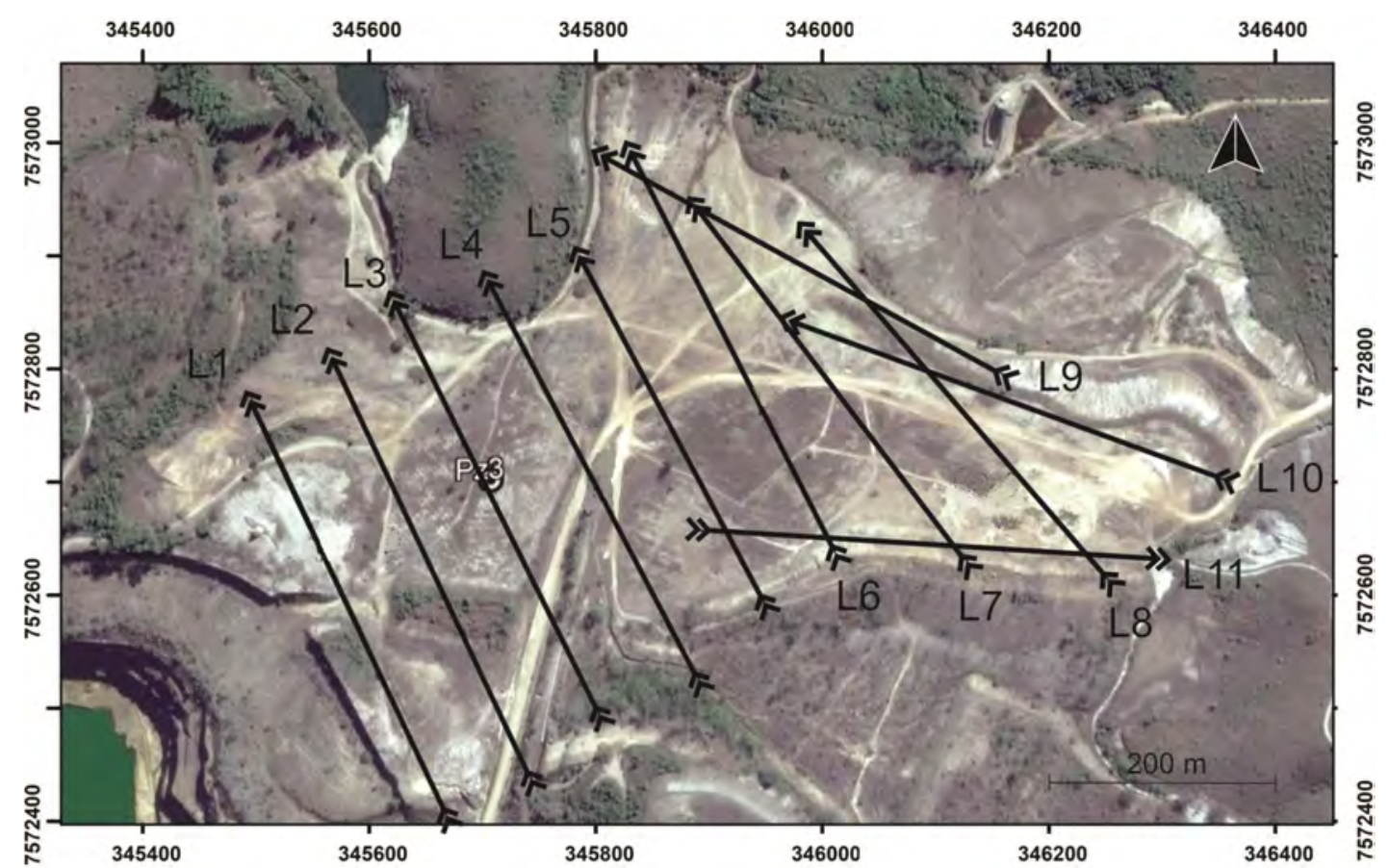

Figure 3 - Arrangement of the geophysical lines in the lower level of the BF-04 and the piezometer PZ-03 location. The arrows indicate the data acquisition orientation.

Similarly, the presence of metallic minerals, as the sulfides like pyrite, may be characterized by high chargeability anomalies in the subsurface, once these mineral species act like capacitors in the physical environment after applying and cutting an electric current from the land surface. In this case the Induced Polarization method is commonly used to determine the zones of accumulation and sulfides (Campbell \& Fitterman, 2000; Campbell \& Beanland, 2001; Moreira et al., 2012).

The geophysical data related to the mentioned methods were obtained applying the Wenner-Schlumberger arrays in order to have a depth and lateral survey, by means of the electrical imaging technique, providing an anomaly view of the parameters in the subsurface measured by sections.

A total of 11 data acquisition lines were defined, nearly covering the entire BF-04 lower level (Fig. 3), although Line 1 had been defined over the dump pile border, practically over the local original land. The total length of the lines was $400 \mathrm{~m}$, except for Line 5 that had a length of $350 \mathrm{~m}$ due to land particularities. The field equipment was the resistivity meter Terrameter LS from ABEM (2012), Sweden, and the employed electrodes were non polarizable $\left(\mathrm{Cu}_{-} \mathrm{Cu}_{2} \mathrm{SO}_{4}\right)$, with a $10 \mathrm{~m}$ distance between them. The equipment specifications are: power of $250 \mathrm{~W}$, maximum current of $2.5 \mathrm{~A}$ and resolution of $1 \mu \mathrm{V}$, with automatic acquisitions through previous configuration (ABEM, 2012).
The configuration parameters for this work were: current of 1 $\mathrm{A}$, acquisition time of 1.5 second, reading time after power outage of 0.3 second, and reading in two time windows with 0.1 second each, defined according to preliminary tests.

The field data were processed using the Res2Dinv (2D) software, version 3.53 (Geotomo Software), that carries out a smoothness-constraint inversion. The models obtained using this procedure are presented by means of chargeability and electroresistivity sections (depth $x$ distance). The steps to develop the pseudo-3D models of the BF-04 followed the same principles used in the mineral prospecting area, using the Oasis Montaj platform (Geosoft) (GEOTOMO Software, 2003).

\section{RESULTS AND DISCUSSION}

\section{D inversion models}

Below there are some selected inversion models of resistivity and chargeability to present the most relevant data and a discussion of the related chemical processes to the detriment of the proposed geophysical model.

Considering the inversion model related to Line 1 , at $310 \mathrm{~m}$ approximately from the origin, it is possible to identify an anomaly characterized by high resistivity $(>12,000 \Omega . m)$ and chargeability (> $10.1 \mathrm{mV} / \mathrm{V}$ ) (Fig. 4), interpreted as 


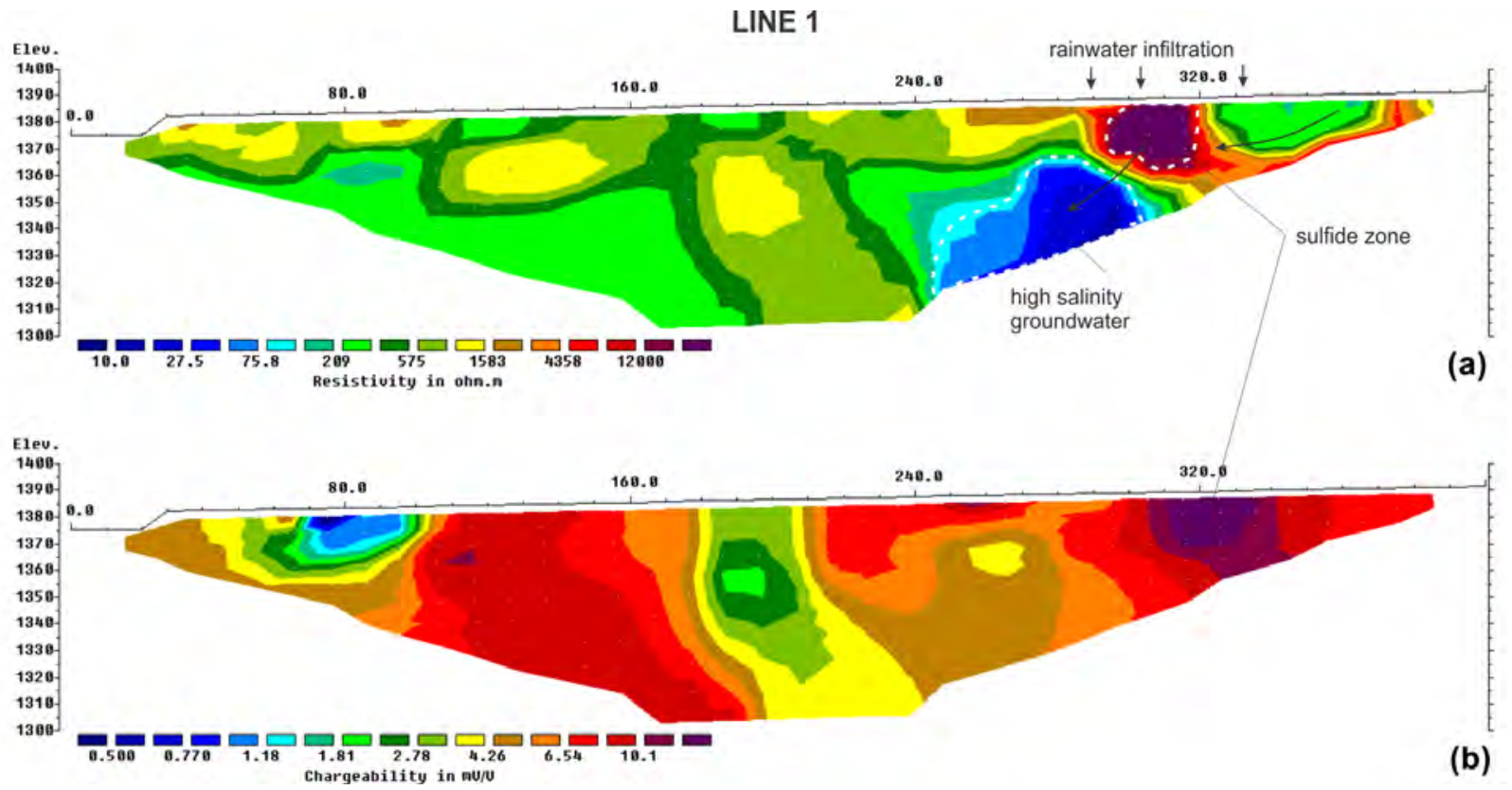

Figure 4 - (a) Resistivity and (b) Chargeability models for Line 1 obtained by inversion. The associated RMS values were $44.4 \%$ and $3.1 \%$ for the resistivity and chargeability inversion models, respectively.
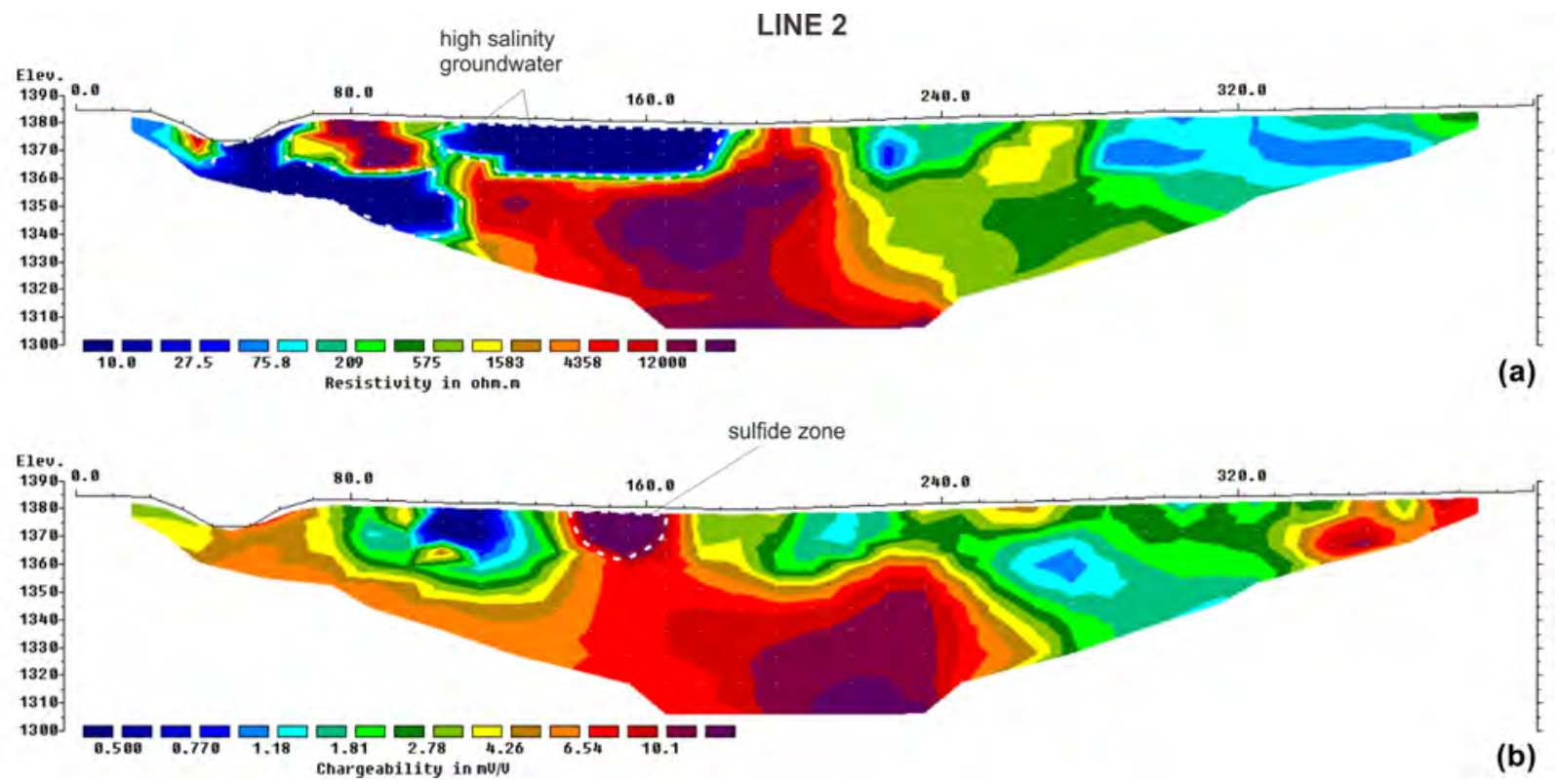

Figure 5 - (a) Resistivity and (b) Chargeability models for Line 2 obtained by inversion. The associated RMS values were $18.2 \%$ and $2.1 \%$ for the resistivity and chargeability inversion models, respectively. 
disseminated sulfides inserted in rocks with silica cement, resulted from the hydrothermal activity in the area. Associated to the referred anomaly there is a significative portion of low resistivity $(<70 \Omega . \mathrm{m})$, considered as acid drainage resulted from the water-ore interaction, especially due to the pluvial water infiltration in the BF-04 region and the reaction with the referred superficial sulfide zone (oxidizing medium). The resistivity range for the aquifer that was not affected by the contamination process was defined from 75 to $209 \Omega$.m, while values up to $1,583 \Omega$.m, that comprise a large portion of the section, would correspond to a significantly altered/fractured bedrock, in face of the thin width of the waste along Line 1.

A similar result can be noted in other geophysical sections. However, in the case of Line 2 inversion model, there is an extensive zone of high resistivity and chargeability in the section center that prolongs itself to larger depths (Fig. 5). The noted resistivity $(>4,000 \Omega . \mathrm{m})$ can be associated to the massive bedrock of the dump pile. In effect, the resistivity indicates the original topography of the suspension conditioning land of the granular aquifer generated by the BF-04, evidenced in turn by the low resistivity superficial anomaly which is lower than $10 \Omega$.m. For comparative purposes, in the work of Anterrieu et al. (2010), the authors define similar values to the contaminated groundwater in a dump pile affected by AMD in Quebec, Canada.

The data from the piezometer $\mathrm{PZ}-03$, with an average $\mathrm{pH} 3.5$, $22.003 \mathrm{mg} / \mathrm{L}$ of $\mathrm{SO}_{4}^{-2}$ and conductivity of $9,853 \mu \mathrm{S} / \mathrm{cm}$ published in Franklin (2007), confirm the geochemical monitoring record described in INB internal reports and describe the continuous production of acid mine drainage since the beginning of the environmental monitoring in 1995. Such data enabled the comparison of the proposed geophysical model with chemical data.

In Figure 6 it was possible to note that the piezometer in question is installed near and over a low resistivity zone in the inversion model of Line 3, which would confirm the acidity and high salinity of the waters collected at this point. There is also a concentration of the low resistivity anomalies in the BF-04, mainly at the distance of 160 meters, where it seems to have an accumulation or a preferential groundwater route due to the cavity of the referred interface. In turn, the chargeability anomalies are related to the rock body, where values over $10.1 \mathrm{mV} / \mathrm{V}$ were obtained. They could contribute to the AMD generation and consequently to the formation of the related low resistivity anomalies. The portions presenting a chargeability around 6.5
$\mathrm{mV} / \mathrm{V}$ that occur superficially were then associated to a waste rich in sulfides (potential oxidation sites).

In the vast majority of the sections that present extremities near the Consulta Creek channel, there was the identification of the low resistivity anomalies characterized by a clear lateral prolongation in the channel direction, which would indicate a probably infiltration of these superficial waters and contribution to the AMD generation. This is the case of the inversion model related to Line 5 (Fig. 7). Notwithstanding, two regions with relatively high chargeability $(>10.1 \mathrm{mV} / \mathrm{V})$ were noted, presenting the main region in its center $(>10.1 \mathrm{mV} / \mathrm{N}, 220$ meters from the origin and at the $1,360 \mathrm{~m}$ quota, and at the final extremity). These regions are related to the sulfide presence although there are also significant portions of the bedrock and of the BF-04 (more superficial level) with chargeability values lower than $0.77 \mathrm{mV} / \mathrm{V}$.

The low resistivity anomaly related to the AMD, according to the evaluation of the 11 inversion models, showed an expressive area increase upstream the dump pile, where Line 9 were acquired, near the BF-04 limit (Fig. 8). This expressive increase would be explained by the convergence tendency of the BF-04 groundwater towards the BNF retention pond. The slope base region, where the contaminated groundwater emerges and is channeled up to the BNF (Fig. 2C), is exactly aligned to the $<10 \Omega$.m anomaly of the referred section, besides having a correspondence with the high chargeability sulfide region ( $>10.1$ $\mathrm{mV} / \mathrm{V}$ ) at the center. In spite of the probable oxygen diffusion facilitation through the BF-04 slope, these sulfide portions seem to resist the oxidizing processes, whose remnants still contribute to generate the AMD.

In this case the large width of the aquifer saturated zone explains the larger dump depth in the region of the acquirement Line 9.

In general, analyzing the 11 inversion models, it was possible to summarize the associations between the resistivity and chargeability anomalies into 3 main groups based on the proposed geophysical model: zones with high resistivity $(>1,583$ $\Omega . \mathrm{m})$ and chargeability $(>10.1 \mathrm{mV} / \mathrm{V})$ values, zones presenting low resistivity $(<70 \Omega . m)$ related to high chargeability anomalies $(>10.1 \mathrm{mV} / \mathrm{V})$ and zones with low chargeability $<10.1 \mathrm{mV} / \mathrm{N}$ associated to resistivity portions that vary from $10 \Omega . m$ to $1,583 \Omega$.m.

The first group is noted in sections 1 and 2 and was associated to sulfide portions in the presence of resistive 

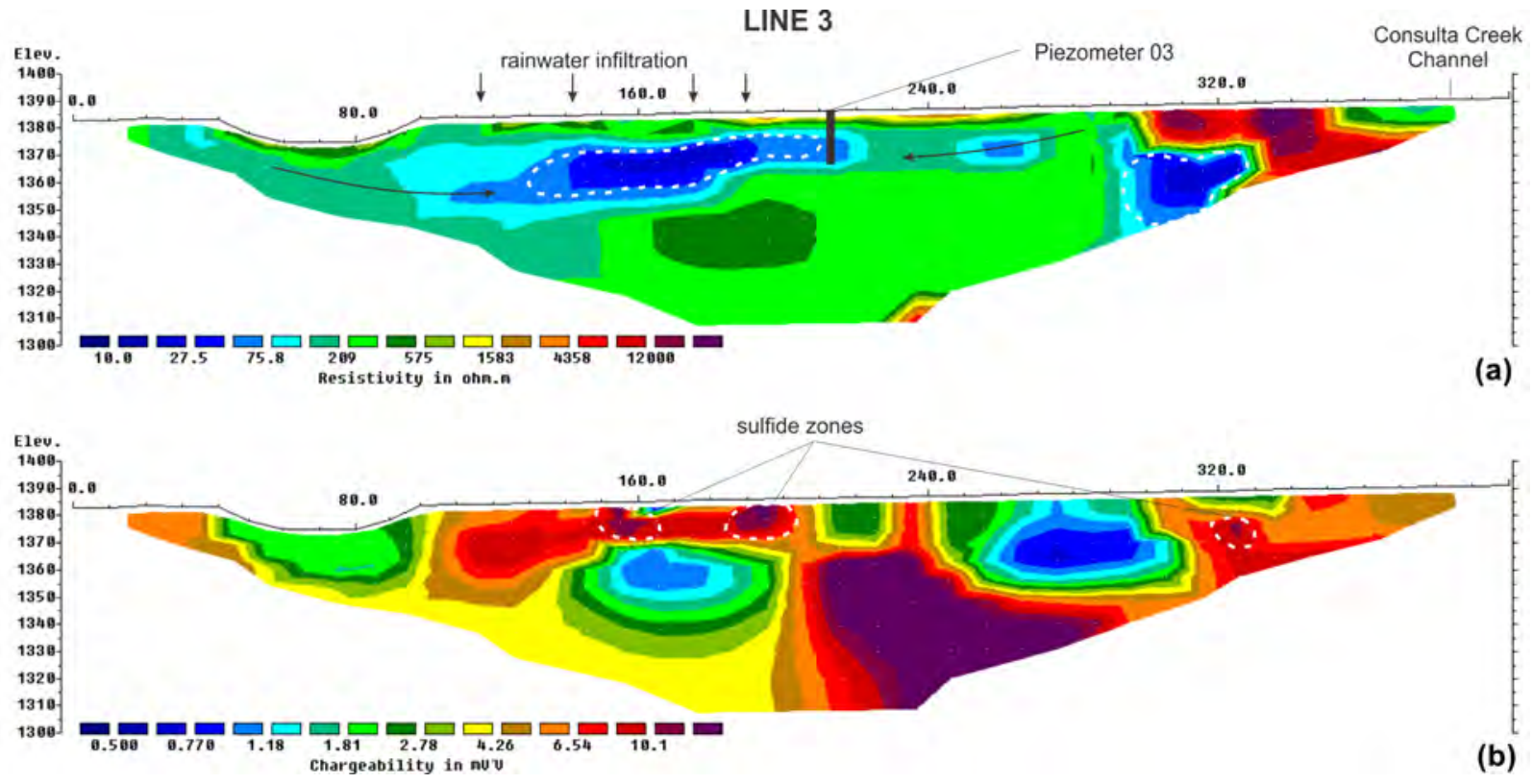

Figure 6 - (a) Resistivity and (b) Chargeability models for Line 3, obtained by inversion and with the piezometer PZ-03 location. The associated RMS values were $18.6 \%$ and $3.1 \%$ for the inversion models for resistivity and chargeability, respectively.

\section{LINE 5}
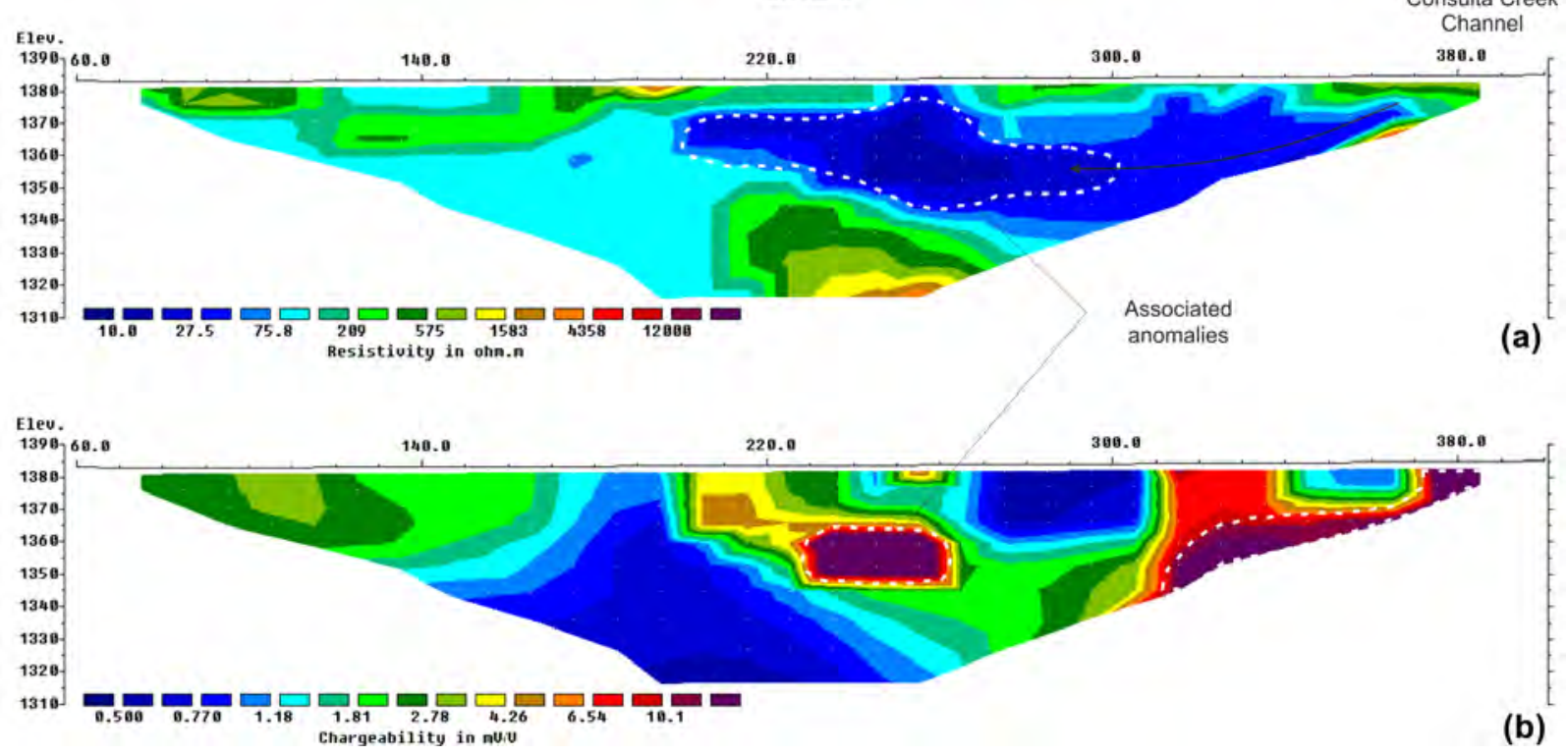

Figure 7 - (a) Resistivity and (b) Chargeability models for Line 5 obtained by inversion. The associated RMS values were 3.2\% and $2.3 \%$ for the resistivity and chargeability inversion models, respectively. 
minerals. In most cases the group was related to the BF-04 basement rocks.

The second group occurs in most of the inversion models and it includes the models related to lines 2, 5 and 9. It is exclusively inserted into the BF-04 waste material, where the high chargeability values describe the sulfide portions with a disseminated nature in the saturated zone of the granular aquiferous system and also affected by the AMD process. This specific group is the primary interest of the research, because it sets up the main regions of oxidation and of acid drainage generation. Although the sulfide concentration in the waste is $2 \%$, the presence of these anomalies suggests much richer nucleus in the sulfide mineral.

Finally, in the third group, the low chargeability anomalies are inserted in the basement and also in the BF-04 and are interpreted as zones with significantly lower sulfide concentrations due to the chargeability decrease. In shallower dump levels these anomalies could be considered as regions that had already been oxidated and thus relatively inert to generate the acid effluent.

\section{Pseudo-3D models}

The inversion model interpolation enabled the investigation at levels of the anomaly sets that were identified before, mainly at the most superficial quotas where there is more interaction with the atmospheric $\mathrm{O}_{2}$ and thus a higher sulfide oxidating potential. Figure 9 presents a more superficial level of the resistivity and chargeability parameters.

The low resistivity anomalies, previously associated to the AMD, form a prolongation in the BF-04 area, evidencing a shallow hydrogeological flow (Fig. 9a). This characteristic may indicate a shallow saline aquifer, with a NE flow towards the BNF. It is very likely that the pluvial water acts mostly in the generation of this main flow by the percolation in less sealed portions of the dump pile surface. The infiltration that comes from the local creek channel also represents an infiltration source for the BF-04 aquiferous system, as it is noted in the inversion models. Hence, these two waterflows towards the internal part of the dump pile are directly related to the unappropriated sealing of its summit and also of the Consulta Creek diversion channel.

In the regions with a higher potential of chemical reaction and AMD generation, it is fundamental to delimit the high chargeability zones in the BF-04 that are associated to the groundwater flows, according to the characteristics defined for group 2. There was an identification of many portions with a chargeability over $10.1 \mathrm{mV} / \mathrm{V}$ at the shallowest levels of the BF-04 and that certainly have a more relevant role in the sulfide oxidation and triggering of the AMD generation cycle (Fig. 9b). The correlation between the two models at the superficial quota enables the identification of these regions where there is

\section{LINE 9}

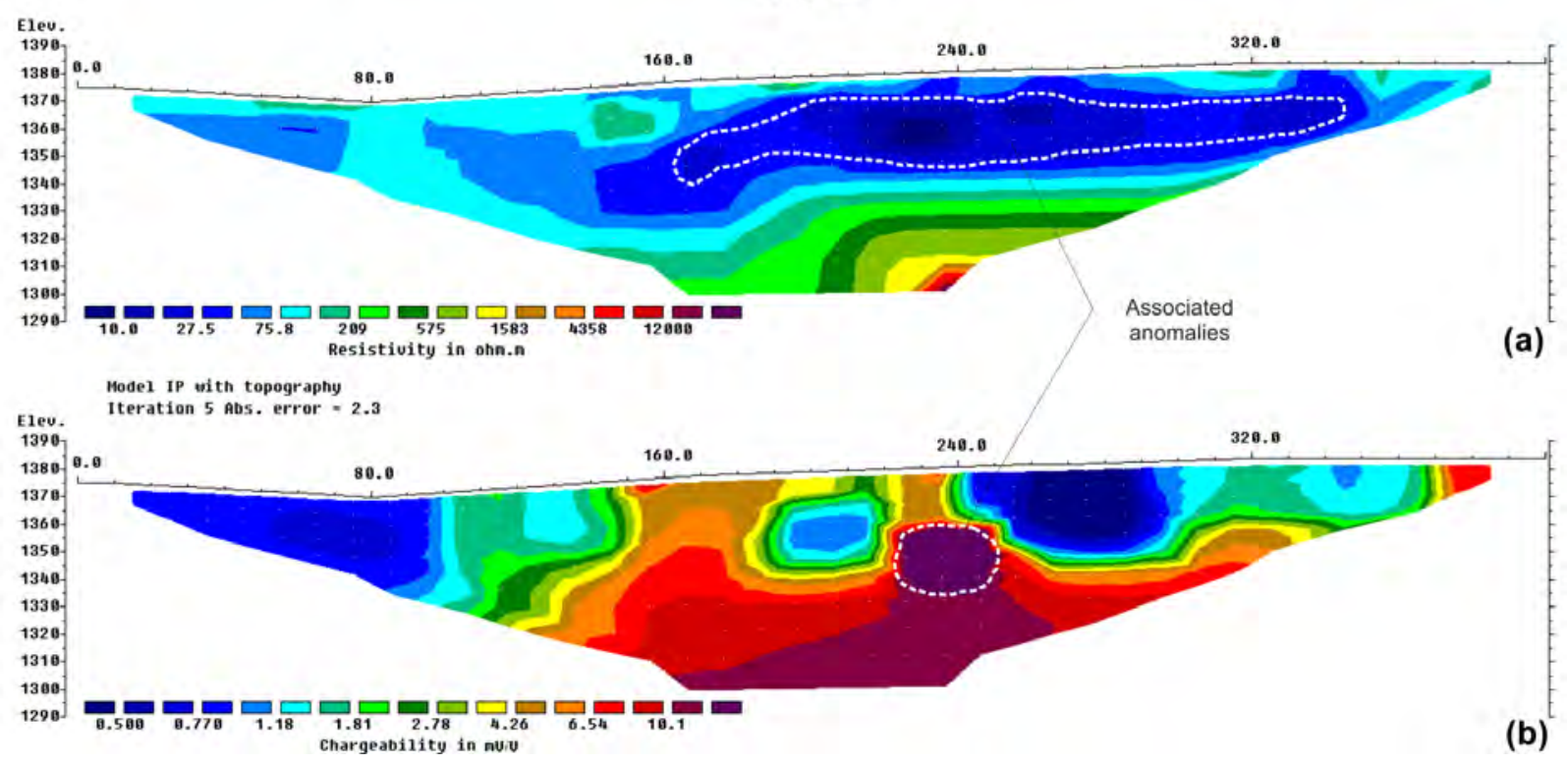

Figure 8 - (a) Resistivity and (b) Chargeability models for Line 9 obtained by inversion. The associated RMS values were $4.4 \%$ and $2.5 \%$ for the resistivity and chargeability inversion models, respectively. 


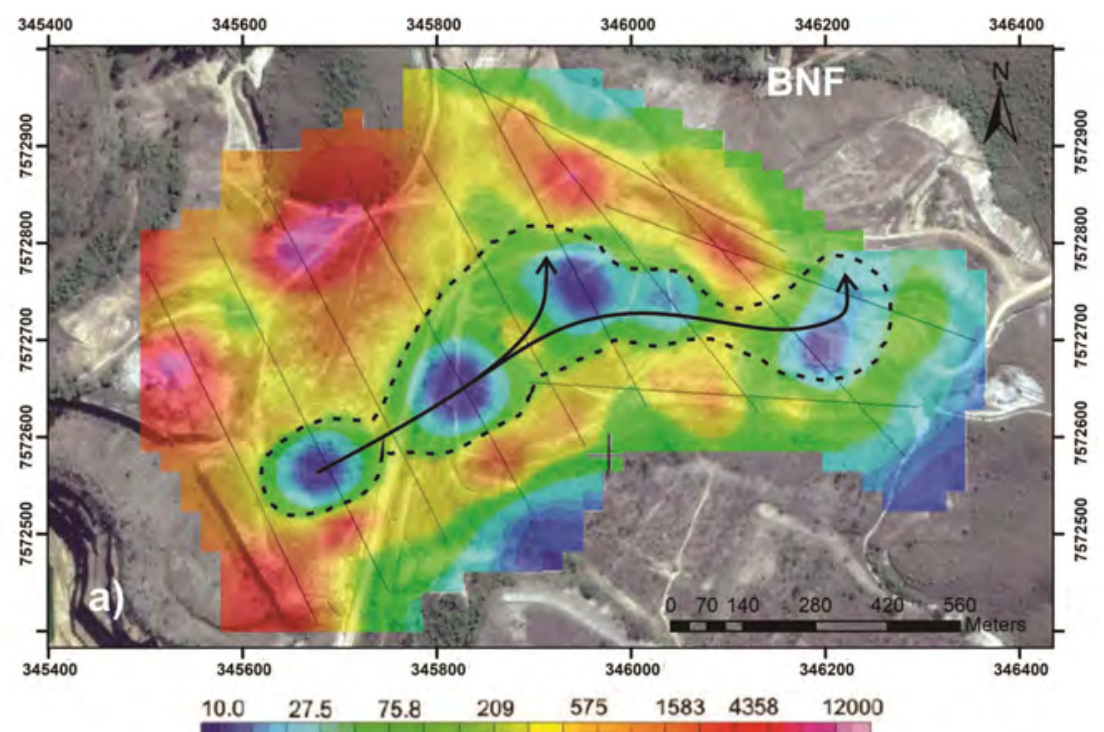

Resistivity in $\Omega \cdot m$

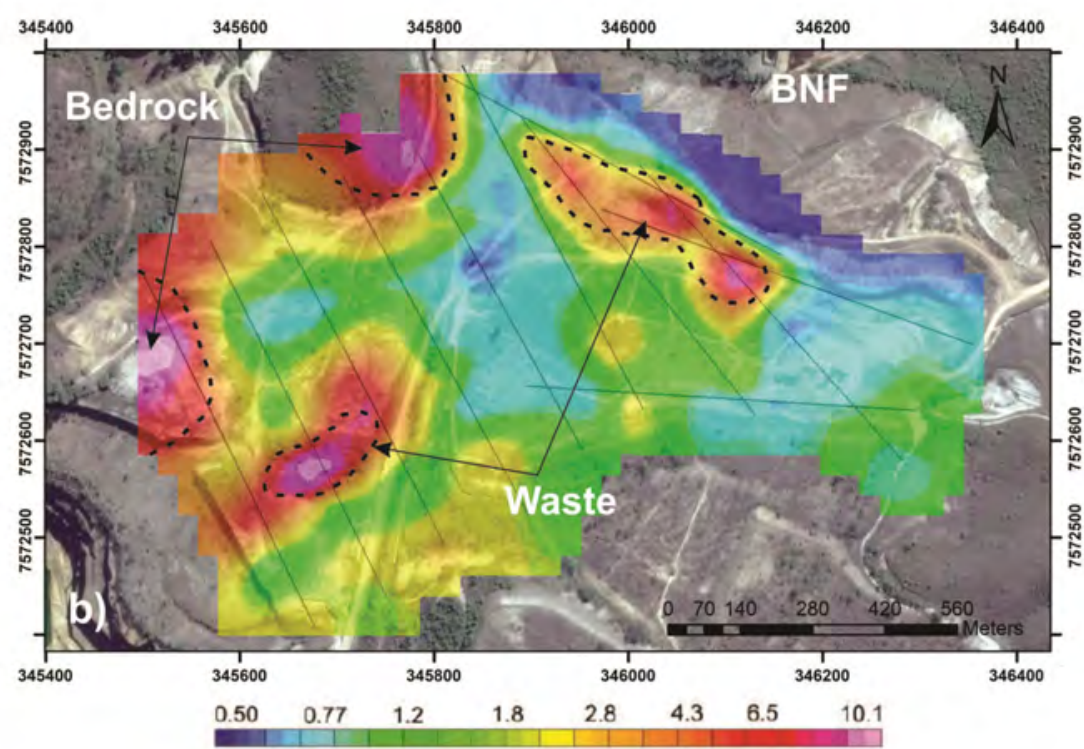

Chargeability in $\mathrm{mV} / \mathrm{V}$

Figure 9 - (a) Resistivity and (b) Chargeability maps for the 1395 m quota, indicating the most relevant anomalies.

the association of low resistivity zones with high chargeability portions, which are crucial for planning the remedying methods of the area.

In contrast, the high chargeability portions in the eastern and northwestern ends of the BF-04 are related to the sulfides of the bedrock itself, due to the thin thickness of the tailing material in these locations. The AMD generation in these locations of the fractured aquifer is not ruled out and its migration to the BF-04 porous system by flows in fractures are not either.

\section{CONCLUSIONS}

The proposed method set was consistent in the study of the groundwater dynamics in the granular aquiferous system, especially in the identification of flow patterns in the dump pile ( $<70 \Omega$.m). There was also the identification of important nucleus in the generation of the acid mine drainage process, with high chargeability anomalies $(>10.1 \mathrm{mV} / \mathrm{N})$ related to sulfides disseminated in the waste material or in the bedrock itself. 
The groundwater in the granular aquiferous system would be mainly fed by pluvial water infiltration and, in a subordinated form, by the Consulta Creek, where it would react with the sulfides to generate effluents with high salinity, low pH and high concentrations of dissolved metals, detected as low resistivity anomalies with minimum values lower than $10 \Omega . m$. This groundwater has a NW main flow by the center of the BF-04, condicioned by the physical heterogeneities of the BF-04 and original topography of the land. The geophysical data could be correlated to direct data of chemical analyses, reinforcing the proposed geophysical model, chiefly to support the location of more monitoring wells in the area.

The role of the indication of these potential zones for the sulfide oxidation and the underground flow dynamics is to help the study, planning and execution of the measures for the area recovery. Among the remedying hypotheses, it is the AMD containment through a direct attack on these zones, either separating the location of these sulfide portions or physically removing this material and returning to the pit. Another mitigation possibility of the chemical process is to strengthen the sealing of the BF-04 surface and also of the artificial channel of the Consulta Creek, as the lack of this measure for the channel and the weathering of the clay layer over the dump pile are the main factors that trigger the local contamination because they enable the water percolation in the system and the consequent contamination generation.

It is important to note that the proposed remediation measures have a potential for drastically reducing the local contamination. Nevertheless, the most realistic scenario is that these measure must ensure an effluent with salinity and $\mathrm{pH}$ closer to acceptable levels defined in legislation, with the possibility of reducing treatment costs or even the direct water release in local superficial water bodies, capable of incorporating and diluting these waters without damaging the natural environment.

\section{ACKNOWLEDGEMENTS}

The authors would like to thank the Fundação de Amparo à Pesquisa do Estado de São Paulo (FAPESP) for the financial support whereby process number 2018/14565-3 (Regular Project), the Applied Geology Department of UNESP - Rio Claro for the availability of the geophysical equipment and the Indústrias Nucleares do Brasil (INB) for the provided access to the study area.

\section{REFERENCES}

ABDELOUAS A. 2006. Uranium mill tailings: geochemistry, mineralogy, and environmental impact. Elements, 2(6): 335-341.

ABEM. 2012. Terrameter LS Instruction Manual. ABEM Instrument AB. Sundbyberg, Sweden. 122 pp.

AKCIL A \& KOLDAS S. 2006. Acid mine drainage (AMD): causes, treatment and case studies. Journal of Cleaner Production, 14(12-13): 1139-1145.

ANTERRIEU 0, CHOUTEAU M \& AUBERTIN M. 2010. Geophysical characterization of the large-scale internal structure of a waste rock pile from a hard rock mine. Bulletin of Engineering Geology and the Environment, 69(4): 533-548.

BLOWES DW. 1997. The environmental effects of mine wastes. In: Proceedings of Exploration 97: Decennial International Conference on Mineral Exploration, p. 887-892. Toronto, Canada: Prospectors and Developers Association.

CAMPBELL DL \& BEANLAND S. 2001. Spectral Induced Polarization Measurements at the Carlisle Mine Dump, New Mexico. Open-File Report 01-363. US Geological Survey. 11 pp.

CAMPBELL DL \& FITTERMAN DV. 2000. Geoelectrical methods for investigating mine dumps. In: Proceedings of the 5th International Conference on Acid Rock Drainage (ICARD 2000), Denver, Colo. Volume 2, p. 1513-1523.

CAMPBELL DL, HORTON RJ \& BEANLAND S. 2000. Geoelectrical laboratory measurements of materials from the May Day Mine dump, southwestern Colorado. Open-File Report 00-382. US Geological Survey. $27 \mathrm{pp}$.

CAPOVILLA MMGM. 2001. Urânio nos hidrotermalitos potássicos (rocha potássica) da mina Osamu Utsumi, Complexo Alcalino de Poços de Caldas, MG. Ph.D. thesis. Universidade de São Paulo. Brazil. 149 pp.

CARVALHO FP, MADRUGA MJ, REIS MC, ALVES JG, OLIVEIRA JM, GOUVEIA J \& SILVA L. 2007. Radioactivity in the environment around past radium and uranium mining sites of Portugal. Journal of Environmental Radioactivity, 96(1-3): 39-46.

CETESB. 2016. Poluição das águas subterrâneas. Companhia Ambiental do Estado de São Paulo. Available on: <http://aguassubterraneas.cetesb. sp.gov.br/poluicao-das-aguas-subterraneas/>. Access on: September 16, 2016.

CIPRIANI M. 2002. Mitigação dos impactos sociais e ambientais decorrentes do fechamento definitivo de minas de urânio. Ph.D. thesis. Instituto de Geociências, Universidade Estadual de Campinas. Campinas, Brazil. 332 pp.

CORSEUIL HX \& MARINS MDM. 1997. Contaminação de águas subterrâneas por derramamentos de gasolina: 0 problema é grave. Revista Engenharia Sanitária e Ambiental, 2(2): 50-54. 
FACHIN SJS, HUBER F, SHIRAIWA S, BORGES WR \& MIGLIORINI RB. 2006. Aplicação de métodos geofísicos para identificar áreas contaminadas por resíduos de um curtume. Brazilian Journal of Geophysics, 24(1): 129-138.

FERNANDES HM, FRANKLIN MR \& VEIGA LH. 1998. Acid rock drainage and radiological environmental impacts. A study case of the Uranium mining and milling facilities at Poços de Caldas. Waste Management, 18(3): 169-181.

FRAENKEL MO, SANTOS RC, LOURENÇO FEVL \& MUNIZ WS. 1985. Jazida de urânio no planalto de Poços de Caldas, Minas Gerais. In: SCHOBBENHAUS C \& COELHO CES (Coords.). Principais depósitos minerais do Brasil - Recursos Minerais Energéticos, chapter 5, p. 89-103. Brasília-DF, Brazil: DNPM.

FRANKLIN MR. 2007. Modelagem numérica do escoamento hidrológico e dos processos geoquímicos aplicados à previsão da drenagem ácida em uma pilha de estéril da mina de urânio de Poços de Caldas-MG. Ph.D. thesis. Universidade Federal do Rio de Janeiro. Brazil. 337 pp.

GEOTOMO Software. 2003. Res2Dinv Version 3.53, Rapid 2D Resistivity \& IP Inversion using the Least-squares Method - Geoelectrical Imaging 2-D \& 3D. User's Manual, 129 pp.

HELENE LPI, MOREIRA CA \& CARRAZZA LP. 2016. Applied geophysics on a soil contaminated site by chromium of a tannery in Motuca (SP, Brazil). Brazilian Journal of Geophysics, 34(3): 309-317.
HOLMES DC, PITTY AE \& NOY DJ. 1992. Geomorphological and hydrogeological features of the Poços de Caldas caldera analogue study sites. Journal of Geochemical Exploration, 45(1-3): 215-247.

LEITE JSM. 2010. Previsão de drenagem ácida por meio de testes estáticos do material do bota fora 4 da mina Osamu Utsumi Caldas/MG. Master's dissertation. Programa de Pós-Graduação em Evolução Crustal e Recursos Naturais. Departamento de Geologia. Escola de Minas, Universidade Federal de Ouro Preto. MG, Brazil. 59 pp.

MOREIRA CA, CARRARA A, HELENE LPI, HANSEN MAF, MALAGUTTI FILHO W \& DOURADO JC. 2017. Electrical resistivity tomography (ERT) applied in the detection of inorganic contaminants in suspended aquifer in Leme city (Brazil). Brazilian Journal of Geophysics, 35(3): 213-225.

MOREIRA CA, LOPES SM, SCHWEIG C \& SEIXAS AR. 2012. Geoelectrical prospection of disseminated sulfide mineral occurrences in Camaquã sedimentary basin, Rio Grande do Sul state, Brazil. Brazilian Journal of Geophysics, 30(2): 169-179.

SILVA RWC, MALAGUTTI FILHO W \& MOREIRA CA. 2009. Emprego do método da eletrorresistividade no estudo da contaminação subterrânea do cemitério municipal de Vila Rezende, Piracicaba-SP. Brazilian Journal of Geophysics, 27(3): 389-399.

VELOSO DIK, MOREIRA CA \& CÔRTES ARP. 2015. Integration of geoelectrical methods in the diagnostic of a diesel contaminated site in Santa Ernestina (SP, Brazil). Brazilian Journal of Geophysics, 33(4): 667-676. 